\title{
Kajian Perhitungan Struktur Atas Bangunan Hotel di Kota Jambi
}

\author{
Marisa Lestari, Suhendra*, M. Nuklirullah \\ Program Studi Teknik Sipil Universitas Batanghari Jambi \\ *Correspondence email: suhendra_domas@yahoo.com
}

\begin{abstract}
Abstrak. Penelitian ini bertujuan untuk mengkaji perhitungan struktur hotel yang berlokasi di Kota Jambi. Struktur bangunan beton bertulang dikaji dalam tiga dimensi. Referensi yang dipakai yaitu SNI 2847:2013, SNI 1726:2012, SNI 1727:2013 serta Peraturan Pembebanan Indonesia Untuk Gedung 1987. Alat bantu perhitungan dalam penelitian ini adalah Aplikasi SAP2000 (Student Version), PcaColumn, dan Microsoft Excel. Hasil analisa membuktikan bahwa Kriteria Desain Seismik struktur sama dengan D, hal mana untuk struktur setinggi 39m, sistem struktur penahan Gaya Gempa yang diperbolehkan ialah Sistem Rangka Pemikul Momen Khusus.
\end{abstract}

Kata Kunci: Perencanaan struktur bangunan hotel; SAP2000; PcaColumn

\section{PENDAHULUAN}

Bangunan bertingkat (vertikal) adalah cara penghematan lahan yang digunakan tanpa harus mengecilkan luas efektif serta kawasan pergerakan manusia. Bangunan bertingkat sangat mudah serta menguntungkan.

Perencanaan struktur bisa diartikan sebagai gabungan antara ilmu pengetahuan dan seni yang digabungkan sama insting seorang pakar struktur tentang sifat struktur berdasarkan pengetahuan di statika, dinamika, mekanika bahan, serta analisis struktur, akan menciptakan bangunan yang ekonomis serta aman, semasa periode pemakaiannya (Agus Setiawan, 2008).

Struktur gedung terdapat 2 bagian yaitu struktur bawah serta struktur atas. Struktur bawah yaitu pondasi, Pile Cap, serta dinding Basement. Selain itu struktur atas yaitu pelat lantai, balok, kolom, serta struktur atap.

Sehingga pada Kajian Perhitungan Struktur Atas Hotel ini bisa digunakan menjadi bahan penelitian serta menganalisa perhitungan yang ada dengan mengacu peraturan yang berlaku di Indonesia yang bermaksud mengenal efesiensi dari bangunan itu sendiri.

Berdasarkan SNI 1726:2012 suatu struktur dapat terancang dari sejumlah komponen, serta perilaku yang berbeda. Menurut komponen penyusunnya, struktur bisa dibedakan 4 macam diantaranya Struktur Balok-Kolom, Struktur Trusses, Struktur Frame, serta Struktur Shell).

Persyaratan perencanaan struktur penahan gempa di Indonesia yaitu SNI 1726:2012 ialah kaidah penting merencanakan struktur penahan gempa di Indonesia, menurut kaidah itu sendiri bahwa struktur yang dapat menahan gempa perlu di rancang dengan:

1. Perencanaan Kapasitas;

2. Struktur Rangka Pemikul Momen;

3. Persyaratan Detailing Hubungan Balok-Kolom.

Menurut SNI 1727:2013 beban yaitu gaya yang ditimbulkan dari beban semua material bangunan, penghuni, perabotan yang ada pada bangunan gedung, dampak lingkungan, jarak pergeseran, serta gaya kekangan efek perubahan ukuran. Mengenai pembebanan yang terdapat di struktur antara lain :

1. Beban Mati (Dead Loads)

Beban mati merupakan beban semua material bangunan gedung tersemat, termasuk dinding, lantai, atap, plafond, tangga, dinding partisi tetap, finishing, klading gedung serta bagian arsitektural serta struktural lainnya.

2. Beban Hidup (Live Loads)

Beban hidup yaitu berat yang ditimbulkan karena pemakai serta penghuni bangunan gedung maupun struktur lain yang bukan tergolong berat konstruksi serta beban lingkungan.

3. Beban Angin (Wind Loads)

Beban angin yaitu seluruh beban yang ada di gedung maupun elemen gedung yang diakibatkan perbedaan dalam tekanan.

4. Beban Gempa

Bedasarkan SNI 1726:2012 dampak gempa rencana yang mesti dilihat pada perencanaan serta penilaian struktur bangunan gedung serta non gedung maupun bermacam komponen perlengkapannya. Gempa rencana dinyatakan seperti mana gempa beserta peluang terlalui besarnya masa usia struktur lama bangunan 50 tahun yaitu $>2 \%$. 
Kombinasi pembebanan ialah kekuatan yang diperlukan elemen - elemen struktur guna mencegah beban terfakor yang bertugas secara bermacam elemen akibat beban dinyatakan kuat perlu (U), kuat perlu ialah kekuatan elemen struktur maupun penampang yang digunakan buat mencegah beban terfaktor maupun momen serta gaya dalam, faktor keamanan gabungan pembebanan yang berdasarkan SNI 2847:2013.

Kekuatan desain ialah kekuatan nominal yang dikalikan sama faktor reduksi kekuatan, kekuatan desain yang terdapat di elemen struktur, sambungannya serta elemen struktur lain, serta penampangnya, sehubungan sama lentur, beban normal, geser, serta torsi perlu digunakan sebesar kekuatan nominal dianalisis serasi sama acuan serta hipotesis dari subpasal 9.3.2 SNI 2847:2013, yang dikalikan sama faktor reduksi kekuatan $\phi$.

SAP2000 ialah suatu program analisis struktur yang komplit serta benar - benar praktis buat digunakan. SAP2000 ini secara komplit terhubung pada Microsoft Windows. Dasar dominan pemakaian program ini ialah pemodelan struktur, eksekusi analisa serta pemeriksaan maupun optimal desain: yang seluruhnya dilakukan pada suatu tahap maupun suatu bentuk.

PcaColumn yaitu suatu program yang berguna mendesain maupun menginvestigasi struktur kolom. Selanjutnya memulai analisa struktur secara manual atau memakai aplikasi, serta didapat gaya - gaya yang bekerja di kolom, maka tahap selanjutnya ialah membuat desain tulangan kolom.

\section{METODE}

Dalam penelitian ini dirancang struktur bangunan gedung hotel 12 lantai menggunakan konstruksi beton bertulang. Menurut perhitungan struktur gedung Hotel penulis mengacu pada standar yang ada di Indonesia. Selain itu juga memakai program aplikasi komputer yang meringankan saat proses analisa berupa SAP2000 Student Version.

Sumber: Data Olahan, 2019

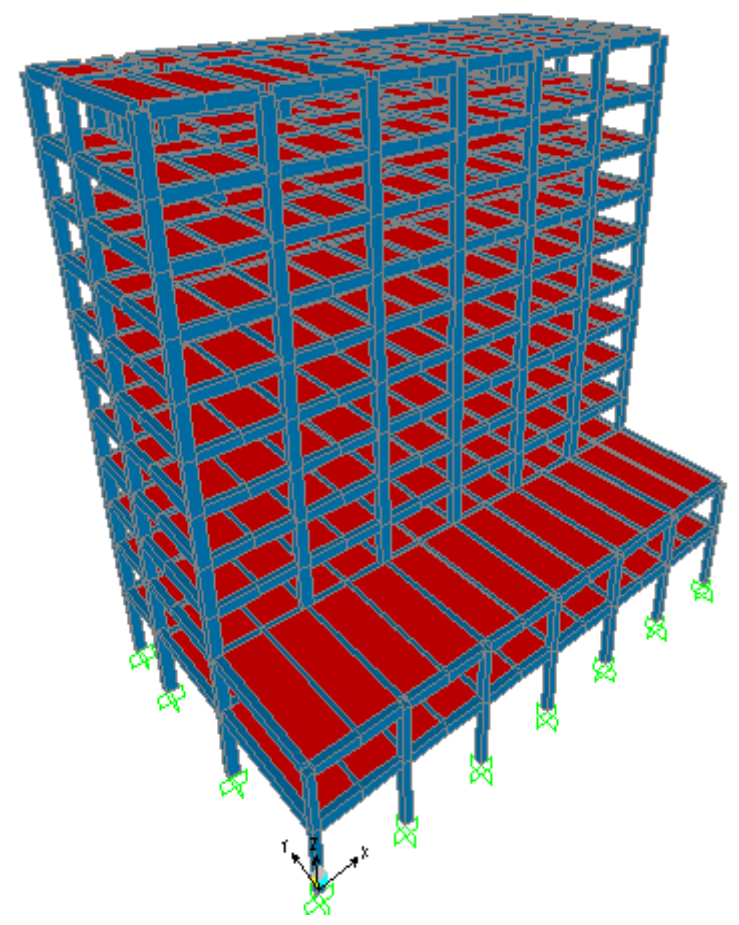

Gambar 1 Pemodelan Struktur 3 Dimensi

\section{Spesifikasi Bangunan}

Spesifikasi bangunan stuktur diantaranya:

- Fungsi stuktur : Bangunan hotel

- Jumlah lantai : 12 lantai

- Basement : 1 basement

T. Basement : 3,6 m

- T. L. Dasar : $5 \mathrm{~m}$

- T. L. $2: 4 \mathrm{~m}$

- T. L. 3 - L. $11: 3,3 \mathrm{~m}$

- T. L. $12: 3,6 \mathrm{~m}$

Tinggi seluruh struktur $39 \mathrm{~m}$ dari permukaan tanah dasar

- Panjang struktur : $38,4 \mathrm{~m}$

- Lebar L. Basement - L. 3 : 23,975 m 
- Lebar L.4 - L. 12 : 14,05 m

- Struktur bangunan : Beton bertulang

- Mutu material :

$\checkmark$ Beton f'c : $30 \mathrm{MPa}$ Ec: $4700 \sqrt{\mathrm{f}^{\prime c} \mathrm{c}}=25742,960 \mathrm{MPa}$

$\checkmark$ Baja BJTD : Ulir fy: $400 \mathrm{Mpa}$ Es $=200000 \mathrm{Mpa}$

- Lokasi : Jl. Jendral Sudirman RT.25 Kel. Tambak Sari Kec. Jambi Selatan, (Thehok)

Kota Jambi

\section{Metode Perhitungan}

1. Beban

Desain yang dipakai buat pembebanan menggunakan SNI 1727:2013 (Beban Minimum Untuk Perancangan Bangunan Gedung dan Struktur Lain).

2. Fungsi bangunan

Acuan yang dipakai buat fungsi bangunan menggunakan SNI 1726:2012 (Tata Cara Perencanaan Ketahanan Gempa Untuk Struktur Bangunan Gedung dan Non Gedung).

3. Klasifikasi situs untuk Kategori Desain Seismik (KDS)

Acuan yang dipakai SNI 1726:2012 (Tata Cara Perencanaan Ketahanan Gempa Untuk Struktur Bangunan Gedung dan Non Gedung).

4. Alat bantu yang dipakai

Alat bantu yang dipakai menganalisa ialah SAP2000 Student Version, Microsoft Excel, dan PcaColumn.

\section{HASIL DAN PEMBAHASAN}

\section{Beban Yang Diperhitungkan}

Beban yang direncanakan bekerja di gedung dengan fungsi hotel, memakai peraturan SNI 1727:2013 serta PPUG 1987 sebagai berikut:

1. Beban Mati:

- Beton Bertulang $=24 \mathrm{kNm}^{-3}$

- Mortar, spesi $=22 \mathrm{kNm}^{-3}$

- Dinding Pasangan Bata $1 / 2$ Batu $=2,5 \mathrm{kNm}^{-2}$

- Plafond + Penggantung $=0,2 \mathrm{kNm}^{-3}$

- Marmer, Granit Per cm Tebal =0,24 kNm${ }^{-2}$

- Instalasi Plumbing $(M E)=0,25 \mathrm{kNm}^{-2}$

- Curtain Wall Kaca + Rangka $=0,6 \mathrm{kNm}^{-2}$

- Cladding Metal Sheet + Rangka =0,2 $\mathrm{kNm}^{-2}$

- Waterproofing $=0,05 \mathrm{kNm}^{-2}$

2. Beban Hidup:

- Hunian Hotel $=1,92 \mathrm{kNm}^{-2}$

- Partisi $=0,72 \mathrm{kNm}^{-2}$

- Air Hujan $=10 \mathrm{kNm}^{-3}$

- Atap $=0,96 \mathrm{kNm}^{-2}$

\section{Analisis Beban Gempa \\ Respon Spektrum Desain}

Disebabkan data tanah tidak diketahui, sehingga tanah di tempat struktur bangunan Hotel kategorikan menjadi tanah lunak (SE). Penetapan respon spektrum desainnya memakai titik koordinat yang diperoleh dari aplikasi Desain Spektra Indonesia antaranya: 


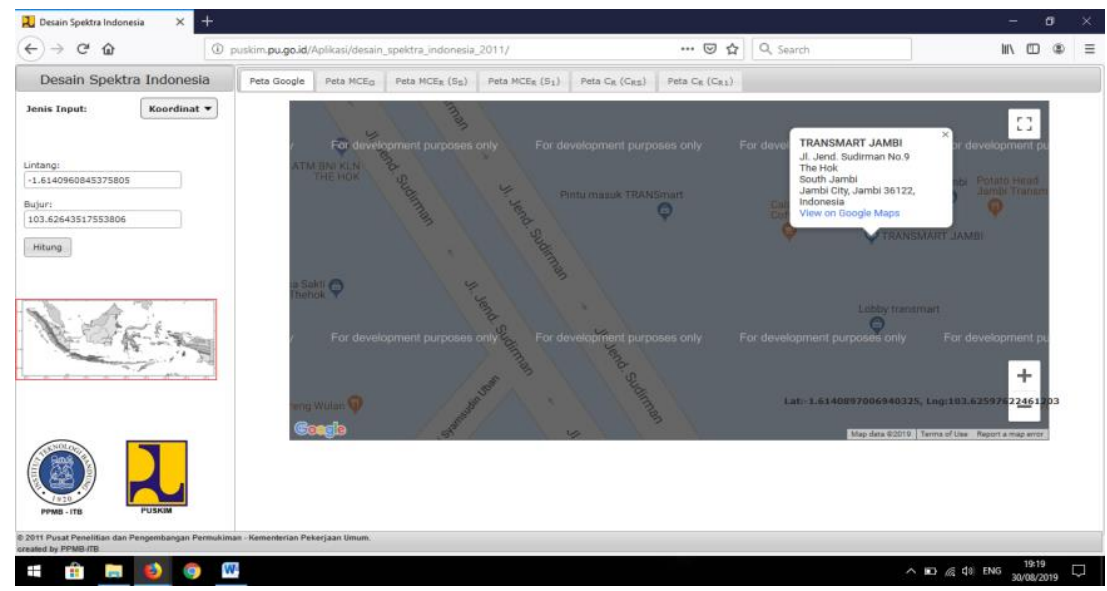

Sumber: http://puskim.pu.go.id/Aplikasi/desain_spektra_indonesia_2011/

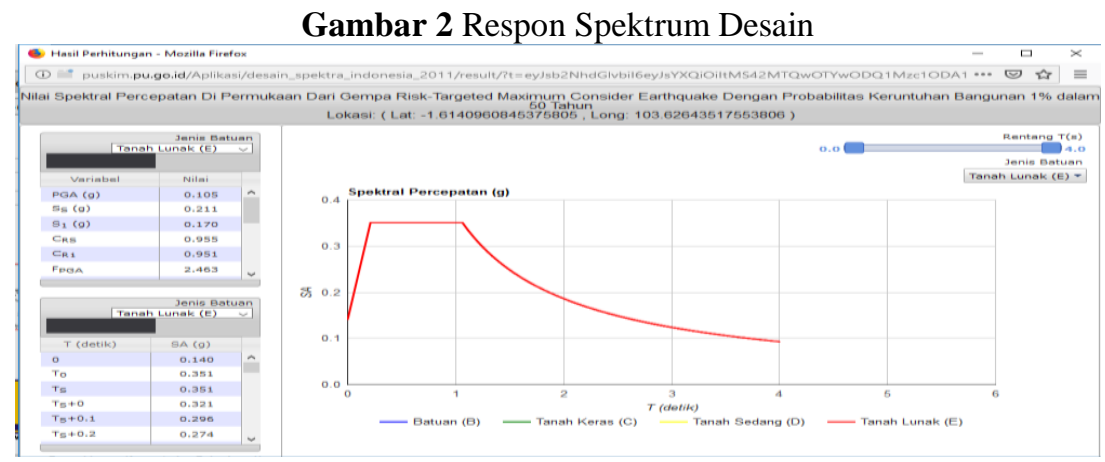

Sumber: http://puskim.pu.go.id/Aplikasi/desain_spektra_indonesia_2011/

Gambar 3 kurva Respon Spektrum Desain

Kurva spektrum desain perlu ditingkatkan serta berpedoman pada persyaratan dibawah ini:

- Untuk periode $\mathrm{T}<\mathrm{T}_{\mathrm{O}^{3}}$

$$
\begin{aligned}
& S_{a}=S_{D S}\left(0,4+0,6 \frac{T}{T_{0}}\right) \\
& S_{a}=0,351\left(0,4+0,6 \frac{0}{0,212}\right)=0,140
\end{aligned}
$$

- Untuk periode $\mathrm{T}$ antara $\mathrm{T}_{\mathrm{O}}$ dan $\mathrm{T}_{\mathrm{S}}$,

$S_{a}=S_{D S}$

$S_{a}=0,351$

- Untuk periode $\mathrm{T}>\mathrm{T}_{\mathrm{S}_{2}}$

$S_{a}=\frac{S_{D 1}}{-T}$

$S_{a}=\frac{0,373}{T}$

\section{Kategori Desain Seismik (KDS)}

Acuan kategori desain seismik struktur bangunan Hotel memakai SNI 1726:2012:

1. Jenis pemanfaatan bangunan yaitu hotel, sehingga berdasarkan Tabel 1 Kategori Resiko Bangunan Gedung dan Non Gedung untuk Beban Gempa dikategori resiko II, maka di Tabel 2 Faktor Keutamaan Gempa, Ie yaitu 1,0;

2. Menurut Kategori Resiko Bangunan (KRB) II serta $S_{\mathrm{DS}}=0.351$, sehingga berdasarkan Tabel 6 KDS bangunan ialah $\mathrm{C}$;

3. Menurut Kategori Resiko Bangunan (KRB) II serta $\mathrm{S}_{\mathrm{D} 1}=0.373$, sehingga berdasarkan Tabel 7 KDS bangunan yaitu D;

Menurut persyaratan diatas, sehingga KDS struktur bangunan Hotel digunakan nilai KDS terbesar adalah D.

\section{Sistem Penahan Gempa}

Menurut fungsi gedung ialah hotel, kategori resiko II serta kategori desain seismik yaitu D, sehingga sistem penahan gaya seismik merupakan Rangka Pemikul Momen Khusus dengan koefisien: 


$$
\begin{aligned}
& \mathrm{R}=8 \\
& \Omega_{0}=3 \\
& \mathrm{C}_{\mathrm{d}}=5,5
\end{aligned}
$$

\section{Penentuan Perioda Gempa}

Menurut data dari Tabel 1 sehingga bisa dianalisa perioda fundamental struktur sebagai berikut:

Tabel 1 Koefisien dan Parameter Perioda

\begin{tabular}{ccc}
\hline Data & Parameter & Keterangan \\
\hline $\mathrm{S}_{\mathrm{D} 1}=0.373$ & $\mathrm{C}_{\mathrm{u}}=1,4$ & Tabel 14 SNI 1726:2012 \\
Rangka Pemikul Momen Khusus & $\mathrm{C}_{\mathrm{t}}=0,0466$ & Tabel 15 SNI 1726:2012 \\
Rangka Pemikul Momen Khusus & $\mathrm{x}=0,9$ & Tabel 15 SNI 1726:2012 \\
\hline
\end{tabular}

Sumber: Tabel 14 dan Tabel 15 SNI 1726:2012

Perioda Fundamental Pendekatan:

$\mathrm{Ta}=\mathrm{C}_{\mathrm{t}} \cdot \mathrm{h}_{\mathrm{n}}^{\mathrm{x}}$

Dengan $\mathrm{h}_{\mathrm{n}}=39 \mathrm{~m}$ dari atas permukaan tanah, sehingga

$\mathrm{Ta}=0,0466 \cdot 39^{0,9}$

$\mathrm{Ta}=1,260$

$\mathrm{Ta}=\mathrm{Tmin}$

Perioda Fundamental Maksimum

$\mathrm{Tmax}=\mathrm{C}_{\mathrm{u}} \cdot \mathrm{Ta}$

$\operatorname{Tmax}=1,4.1,260=1,764$

Jika Tc $>$ Tmax maka $T_{\text {pakai }}=$ Tmax

$\mathrm{Ta} \leq \mathrm{Tc} \leq \mathrm{Tmax}$ maka $\mathrm{T}_{\text {pakai }}=\mathrm{Tc}$

$\mathrm{Ta}>\mathrm{Tc}$ maka $\mathrm{T}_{\text {pakai }}=\mathrm{Ta}$

Menurut perhitungan yang diperoleh dari aplikasi SAP2000 sehingga didapat Periode fundamental struktur (Tc) seperti di tabel berikut ini:

Tabel 2 Tabel Modal Periods

\begin{tabular}{|c|c|c|r|r|r|r|r|}
\hline & $\begin{array}{c}\text { OutputCase } \\
\text { Text }\end{array}$ & $\begin{array}{c}\text { StepType } \\
\text { Text }\end{array}$ & $\begin{array}{r}\text { StepNum } \\
\text { Unitless }\end{array}$ & $\begin{array}{r}\text { Period } \\
\text { Sec }\end{array}$ & $\begin{array}{r}\text { Frequency } \\
\text { Cyc/sec }\end{array}$ & $\begin{array}{r}\text { CircFreq } \\
\text { rad/sec }\end{array}$ & $\begin{array}{r}\text { Eigenvalue } \\
\text { rad2/sec2 }\end{array}$ \\
\hline & MODAL & Mode & 1 & 1,319968 & 0,75759 & 4,7601 & 22,659 \\
\hline & MODAL & Mode & 2 & 1,108082 & 0,90246 & 5,6703 & 32,153 \\
\hline & MODAL & Mode & 3 & 1,03955 & 0,96195 & 6,0441 & 36,532 \\
\hline & MODAL & Mode & 4 & 0,43848 & 2,2806 & 14,329 & 205,33 \\
\hline & MODAL & Mode & 5 & 0,385748 & 2,5924 & 16,288 & 265,31 \\
\hline & MODAL & Mode & 6 & 0,233231 & 4,2876 & 26,94 & 725,75 \\
\hline & MODAL & Mode & 7 & 0,228425 & 4,3778 & 27,507 & 756,61 \\
\hline
\end{tabular}

Sumber: Data Olahan, 2019

Perioda Arah X:

$\mathrm{Tc}>\mathrm{Cu} \mathrm{Ta}$

$1,1080882>1,764$

Maka $\mathrm{T}_{\text {pakai }}=\mathrm{Tc}=1,1080882$

Perioda Arah Y:

$\mathrm{Tc}>\mathrm{Cu} \mathrm{Ta}$

$1,319968>1,764$

Maka $\mathrm{T}_{\text {pakai }}=\mathrm{Tc}=1,231036$

Menurut Tabel 13 SNI 1726:2012 tentang parameter pemakaian prosedur analisis yang bisa dipakai dengan sistem tidak beraturan vertikal struktur sehingga:

$\mathrm{T}<3,5 \mathrm{Ts}$, $(\mathrm{Ts}=1,062$, dari Tabel 4.15)

$\mathrm{Tx}<3,5.1,062$

$1,1080882<3,717 \mathrm{Ya}$ ! 
Ty $<3,5.1,062$

$1,319968<3,717 \mathrm{Ya}$ !

Menurut parameter diatas sehingga bangunan bersama fungsi gedung yaitu hotel, Kategori Resiko II serta KDS D, diizinkan memakai prosedur Analisa Gaya Lateral Ekivalen.

\section{Distribusi Vertikal Beban Gempa Lateral Ekivalen}

Sistem struktur yang dipakai adalah Sistem Penahan Gaya Seismik Sistem Struktur Pemikul Momen Khusus, dengan faktor modifikasi respon $\mathrm{R}=8$.

a. Arah X

$\mathrm{Csx}=\frac{\mathrm{S}_{\mathrm{DS}}}{\frac{\mathrm{R}}{\mathrm{Ie}}}=\frac{0,351}{\frac{8}{1}}=0,0439$

Nilai Cs tidak perlu melebihi dari nilai berikut ini:

$\operatorname{Csx} \max =\frac{\mathrm{S}_{\mathrm{D} 1}}{\mathrm{~T} \cdot\left(\frac{\mathrm{R}}{\mathrm{Ie}}\right)}=\frac{0,373}{1,108082 \cdot\left(\frac{8}{1}\right)}=0,0421$

Nilai Cs harus tidak kurang dari:

Cs $=0,044 . \mathrm{S}_{\mathrm{DS}} . \mathrm{Ie} \geq 0,01$

$=0,044 \cdot 0,351 \cdot 1 \geq 0,01$

$=0,0154 \geq 0,01$

Jadi Csx $=0,0421$

\section{b. Arah Y}

$\mathrm{C}_{\mathrm{SY}}=\frac{\mathrm{S}_{\mathrm{DS}}}{\frac{\mathrm{R}}{\mathrm{Ie}}}=\frac{0,351}{\frac{8}{1}}=0,0439$

Nilai Cs tidak perlu melebihi dari nilai berikut ini:

$\mathrm{C}_{\mathrm{SY}} \max =\frac{\mathrm{S}_{\mathrm{D} 1}}{\mathrm{~T} \cdot\left(\frac{\mathrm{R}}{\mathrm{Ie}}\right)}=\frac{0,373}{1,319968 \cdot\left(\frac{8}{1}\right)}=0,0353$

Nilai Cs harus tidak kurang dari:

$\mathrm{Cs}=0,044 . \mathrm{S}_{\mathrm{DS}} . \mathrm{Ie} \geq 0,01$

$=0,044 \cdot 0,351 \cdot 1 \geq 0,01$

$=0,0171$

Jadi $\mathrm{C}_{\mathrm{SY}}=0,0353$

\section{Gaya Geser Dasar Seismik}

$\mathrm{Vx}=\mathrm{Csx} . \mathrm{Wt}$

$=0,0421.299379,649=12603,883 \mathrm{kN}$

$\mathrm{V}_{\mathrm{Y}}=\mathrm{C}_{\mathrm{SY}} \cdot \mathrm{Wt}$

$=0,0353.299379,649=10568,102 \mathrm{kN}$

\section{Beban Gempa}

$\mathrm{F}=\frac{\mathrm{W} \cdot \mathrm{h}^{\mathrm{k}}}{\sum_{\mathrm{i}=1}^{\mathrm{n}} \mathrm{Wi} \cdot \mathrm{hi}^{\mathrm{x}}} \cdot \mathrm{V}$

Berdasarkan Subpasal 7.8.3 SNI 1726:2012 maka nilai eksponen "k" sebagai berikut:

$\mathrm{Tx}=1,108082$

$\mathrm{kx}=0,5 . \mathrm{T}+0,75=0,5.1,108082+0,75=1,304$

$\mathrm{Ty}=1,319968$

$\mathrm{ky}=0,5 . \mathrm{T}+0,75=0,5.1,319968+0,75=1,410$

Tabel 4 Distribusi Beban Gempa Arah X

\begin{tabular}{|c|c|c|c|c|c|c|}
\hline Lantai & $\begin{array}{l}\text { Berat Efektif } \\
\text { Wi }(\mathrm{kN})\end{array}$ & $\begin{array}{l}\text { Tinggi } \\
\mathrm{h}(\mathrm{m})\end{array}$ & $\mathrm{kx}$ & $\begin{array}{l}\text { Wi . hik } \\
\text { (kN.m) }\end{array}$ & $\begin{array}{c}\mathrm{Vx} \\
(\mathrm{kN})\end{array}$ & $\begin{array}{l}\text { Fx } \\
(\mathrm{kN})\end{array}$ \\
\hline 12 (Atap) & 4535,80074 & 39 & & 538768,524 & & 432,966 \\
\hline 11 & 29917,771 & 35,4 & & 3132055,737 & & 2516,987 \\
\hline 10 & 27347,976 & 32,1 & 1,304 & 2520041,835 & 12603,88 & 2025,160 \\
\hline 9 & 27347,976 & 28,8 & & 2187625,577 & & 1758,023 \\
\hline
\end{tabular}


Sumber: Data Olahan, 2019

$\begin{array}{cc}27347,976 & 25, \\ 27347,976 & 2 \\ 27347,976 & 18 \\ 27347,976 & 15, \\ 27347,976 & 1 \\ 33359,237 & \\ 40131,009 & \\ 299379,6489 & \end{array}$

\begin{tabular}{c}
25,5 \\
22,2 \\
18,9 \\
15,6 \\
12,3 \\
9 \\
5 \\
\hline
\end{tabular}

1866609,981

1558007,224

1263081,520

983466,712

721375,608

585528,908

327293,189

15683854,815

1500,048

1252,048

1015,039

790,335

579,713

470,544 263,020

Tabel 5 Distribusi Beban Gempa Arah Y

\begin{tabular}{|c|c|c|c|c|c|c|}
\hline Lantai & $\begin{array}{c}\text { Berat Efektif } \\
\text { Wi }(\mathrm{kN})\end{array}$ & $\begin{array}{l}\text { Tinggi } \\
\mathrm{h}(\mathrm{m})\end{array}$ & ky & $\begin{array}{l}\text { Wi . hi } \\
\text { (kN.m) }\end{array}$ & $\begin{array}{c}\mathrm{Vy} \\
(\mathrm{kN})\end{array}$ & $\begin{array}{c}\text { Fy } \\
(\mathrm{kN})\end{array}$ \\
\hline 12 (Atap) & 4535,801 & 39 & & 794428,953 & & 381,035 \\
\hline 11 & 29917,771 & 35,4 & & 4571132,687 & & 2192,468 \\
\hline 10 & 27347,976 & 32,1 & & 3639965,640 & & 1745,849 \\
\hline 9 & 27347,976 & 28,8 & & 3123694,810 & & 1498,228 \\
\hline 8 & 27347,976 & 25,5 & & 2631157,483 & & 1261,991 \\
\hline 7 & 27347,976 & 22,2 & 1,41 & 2164127,692 & 10568,102 & 1037,988 \\
\hline 6 & 27347,976 & 18,9 & & 1724790,424 & & 827,267 \\
\hline 5 & 27347,976 & 15,6 & & 1315924,195 & & 631,161 \\
\hline 4 & 27347,976 & 12,3 & & 941220,539 & & 451,441 \\
\hline 3 & 33359,237 & 9 & & 739091,227 & & 354,493 \\
\hline 2 & 40131,009 & 5 & & 388175,202 & & 186,182 \\
\hline Total & 299379,649 & & & 22033708,852 & & \\
\hline
\end{tabular}

Sumber: Data Olahan, 2019

\section{Perhitungan Penulangan Pelat}

Pelat yang akan ditinjau merupakan perwakilan dari setiap lantai yakni pelat L. Dasar, L. 2, L. 3, L. 4 - L. 11, serta L. 12 (Atap). Guna memudahkan pemodelan, sehingga komponen pelat dipakai simbol seperti:

P. L. = Pelat Lantai

P. A. $=$ Pelat Atap

Metode yang dipakai buat perhitungan pelat menggunakan metode koefisien momen.

Tabel 6 Jenis - Jenis Pelat

\begin{tabular}{ccccc}
\hline No & Kode Pelat & Tipe Pelat & Dimensi $(\mathrm{mm})$ & Jenis \\
\hline 1. & P. L. 1 & Pelat Lantai & $3200 \times 5100$ & Pelat dua arah \\
2. & P. L. 2 & Pelat Lantai & $3200 \times 5100$ & Pelat dua arah \\
3. & P. L. 3 & Pelat Lantai & $3200 \times 5400$ & Pelat dua arah \\
4. & P. L. 4 & Pelat Lantai & $3200 \times 5400$ & Pelat dua arah \\
5. & P. A. & Pelat Atap & $3200 \times 5100$ & Pelat dua arah \\
\hline
\end{tabular}

Sumber: Data Olahan, 2019

Mutu bahan yang dipakai:

$\mathrm{fc}^{\prime}=30 \mathrm{MPa}<28 \mathrm{Mpa}$ (SNI 2847-2013, subpasal 10.2.7.3)

Maka, $\beta 1=0,85-0,05\left(\frac{\mathrm{fc}^{\prime}-28}{7}\right) \geq 0,65$

$=0,85-0,05\left(\frac{30-28}{7}\right) \geq 0,65$

$=0,84 \geq 0,65 \ldots$ Ok!

$\mathrm{Ec}=25742,960 \mathrm{MPa}$

$\mathrm{fy}=400 \mathrm{MPa}$

Es $=200000 \mathrm{MPa}$

Tul. Pokok $=\mathrm{D} 12 \mathrm{~mm}$

Tul. Susut $=$ D10 mm

Selimut Beton $(\mathrm{Cc})=20 \mathrm{~mm}$ 
Tabel 7 Tulangan Terpasang Pada Pelat

\begin{tabular}{cccccccc}
\hline & Dimensi (mm) & ly/lx & $\begin{array}{c}\text { Mlx }=- \\
\text { Mtx }\end{array}$ & $\begin{array}{c}\text { Mly } \\
- \text { Mty }\end{array}$ & $\begin{array}{c}\text { Mu } \\
(\mathrm{kN} / \mathrm{m} 2)\end{array}$ & Tul. Pokok & Tul. Susut \\
\hline L. Dasar & $3200 \times 5100$ & 1,6 & 60 & 36 & 13,604 & D12-160 & D10-300 \\
L. 2 & $3200 \times 5100$ & 1,6 & 60 & 36 & 13,844 & D12-200 & D10-250 \\
L. 3 & $3200 \times 5400$ & 1,7 & 59 & 36 & 8,100 & D12-250 & D10-300 \\
L. 4 - L. 11 & $3200 \times 5400$ & 1,7 & 61 & 35 & 8,100 & D12-250 & D10-300 \\
L. 12 (Atap) & $3200 \times 5100$ & 1,6 & 60 & 36 & 9,700 & D12-200 & D10-250 \\
\hline
\end{tabular}

Sumber: Data Olahan, 2019

Perhitungan Penulangan Kolom

Tabel 9 Tulangan Terpasang Pada Kolom

\begin{tabular}{|c|c|c|c|c|c|}
\hline \multirow{3}{*}{ Tingkat } & \multirow{3}{*}{ Tipe Kolom } & \multicolumn{4}{|c|}{ Penulangan } \\
\hline & & \multicolumn{2}{|c|}{ Longitudinal } & \multicolumn{2}{|c|}{ Geser } \\
\hline & & $\mathrm{L}_{0}$ & $>\mathrm{L}_{0}$ & $\mathrm{~L}_{0}$ & $>\mathrm{L}_{0}$ \\
\hline \multirow{2}{*}{ L. Dasar - L. 2} & Kolom $1(550 \mathrm{~mm} \times 550 \mathrm{~mm})$ & $8 \mathrm{D} 22$ & D13-100 & $8 \mathrm{D} 22$ & D13-200 \\
\hline & Kolom $2(600 \mathrm{~mm} \times 800 \mathrm{~mm})$ & $12 \mathrm{D} 25$ & 4D13-100 & $12 \mathrm{D} 25$ & D13-200 \\
\hline L. 3 & Kolom $2(600 \mathrm{~mm} \times 800 \mathrm{~mm})$ & $10 \mathrm{D} 25$ & 3D13-100 & $10 \mathrm{D} 25$ & D13-200 \\
\hline L. 4 - L. 7 & Kolom $2(600 \mathrm{~mm} \times 800 \mathrm{~mm})$ & $10 \mathrm{D} 25$ & 3D13-100 & $10 \mathrm{D} 25$ & D13-200 \\
\hline L. 8 - L. 11 & Kolom $2(600 \mathrm{~mm} \times 800 \mathrm{~mm})$ & $10 \mathrm{D} 25$ & 3D13-100 & $10 \mathrm{D} 25$ & D13-200 \\
\hline
\end{tabular}

Sumber: Data Olahan, 2019

\section{SIMPULAN}

Maka kesimpulan yang didapat dari hasil analisis yaitu:

1. Perencanaan gedung bertingkat ini didesain sama pada standar terkini adalah SNI 2847:2013, SNI 1726:2012, serta Peraturan Pembebanan Indonesia Untuk Gedung 1987.

2. Dari hasil analisis struktur bangunan Hotel tergolong kategori resiko II, serta Kategori Desain Seismik (KDS) bangunan ialah D, maka sistem penahan gaya seismik yaitu Rangka Pemikul Momen Khusus.

3. Pelat terdiri dari pelat lantai sama pelat atap yang mana digunakan tulangan:

- L. Dasar digunakan Tul. Pokok D12-160 serta Tul. Susut D10-300;

- L. 2 digunakan Tul. Pokok D12-200 serta Tul. Susut D10-250;

- L. 3 digunakan L. 4 - L. 11 digunakan Tul. Pokok D12-250 serta Tul. Susut D10-300;

- L. 12 (atap) digunakan Tul. Pokok D12-200 serta Tul. Susut D10-250.

4. Dimensi kolom hasil analisis PcaColumn diperoleh sebagai berikut:

- L. Dasar - L. 2 yaitu K1 = $550 \mathrm{~mm}$ x $550 \mathrm{~mm}$ (8 D22)

serta $\mathrm{K} 2=600 \mathrm{~mm} \times 800 \mathrm{~mm}(12 \mathrm{D} 25)$;

- L. 3 yaitu K2 = $600 \mathrm{~mm} \times 800 \mathrm{~mm}(10 \mathrm{D} 25)$;

- L. 4 - L. 7 yaitu K2 = $600 \mathrm{~mm} \times 800 \mathrm{~mm}(10 \mathrm{D} 25)$;

- L. 8 - L. 11 yaitu K2 $=600 \mathrm{~mm} \times 800 \mathrm{~mm}(10 \mathrm{D} 25)$.

\section{Saran}

Adapun saran yang bisa diberikan penulis ialah:

1. Untuk perencanaan stuktur gedung selain berdasarkan sama persyaratan yang berlaku, kita pun harus mencocokan sama pekerjaan diproyek.

2. Pada akan merancang struktur kita pun perlu mengerti bahan material apa yang berlimpah ditemukan dilokasi pembangunan sehingga kita bisa menggunakan material tersebut secara efektif, dan tentu menghemat biaya.

3. Perkiraan beban serta kombinasi beban yang dipakai wajib hampir sama dengan situasi yang bisa terjadi, sehingga didapat struktur gedung yang aman, nyaman, hemat serta efesien yang sesuai standar yang berlaku.

\section{DAFTAR PUSTAKA}

Anonim, 2019, Pembangunan Hotel Yello. Jambi : PT. Sumaraja Indah

Badan Standarisasi Nasional, 2012, Tata Cara Perencanaan Ketahanan Gempa untuk Bangunan Gedung dan Non Gedung (SNI 1726:2012), Badan Standarisasi Nasional, Jakarta

Badan Standarisasi Nasional, 2013, Persyaratan Beban Minimum untuk Perancangan Bangunan Gedung dan Struktur Lain (SNI 1727:2013), Badan Standarisasi Nasional, Jakarta

Badan Standarisasi Nasional, 2013, Persyaratan Beton Struktural untuk Bangunan Gedung (SNI 2847:2013), Badan Standarisasi Nasional, Jakarta 
Setiawan A, 2008, Perencanaan Struktur Baja Dengan Metode LRFD (Berdasarkan SNI 1729:2002), Erlangga, Semarang

Yayasan Badan Penerbit PU, 1987, Pedoman Perencanaan Pembebanan Untuk Bangunan Rumah dan Gedung, Yayasan Badan Penerbit PU, Jakarta 